\title{
Deconstruction of Ethics in Visual Culture of Memes on Social Media
}

\author{
S Sidhartani ${ }^{1}$, Winny G W Wardani ${ }^{2}$, D Pratama ${ }^{3}$ \\ Visual Communication Design, Faculty of Language and Art, Universitas Indraprasta PGRI, Jl. \\ Nangka No. 58, Tanjung Barat, Jakarta Selatan, Indonesia ${ }^{1,2,3}$ \\ \{santi.sidhartani@unindra.ac.id $\left.{ }^{1}\right\}$
}

\begin{abstract}
The existence of memes on social media has become a visual culture because it can meet the information and pleasure needs of visual technology users. The meme is considered effective for conveying messages to audiences with humorous visual language. However, meme creativity often also uses visual objects that tend to demean other people, such as exploit a woman's body. This is very contrary to ethics, the moral obligation of humans as social-cultural beings, by carrying out acts of gender discrimination and the tendency to make pornographic photos. This has been regulated in UU No. 7 of 1984 concerning the elimination of discrimination and UU No. 44 of 2008 concerning pornography. Quantitatively, this study presents the results of a survey of design student respondents who showed that most memes on social media tend to display sexual exploitation and demeaning others. Whereas qualitatively, this study discusses the deconstruction of ethics in meme design, according to an ethic of responsibility of the 20th Century from Hans Jonas, using sociology of design approach, that is reading the function of visual signs. The results of this study are expected to be able to invite the audience to better understand the visual language of memes, and be critical of the visualization of memes that connote violating moral norms. This study can also be a reference to the visual culture of memes based on more responsible ethics.
\end{abstract}

Keywords: Deconstruction, Ethics, Visual Culture, Memes, Social Media.

\section{Introduction}

The spread of memes through the internet has become a daily visual consumption. The meme can be accessed through social media or shared via instant messaging applications on smartphones. The meme is a communication creation that can take the form of images, photos, or videos, coupled with short words, with parody style to convey ideas from the creator and disseminate to the audience [1]. The development of visual technology has placed memes as a product of visual culture and mass media products. Visual culture defined by Mirzoeff, as a visual event that consumers look for as users of visual technology because it can satisfy their needs for information, as well as pleasure [2].

The presence of memes on social media has the potential to have positive and negative impacts. Positively, the meme can be an effective messenger because it is delivered in a visual style of humor and is easily understood by the audience. Whereas negatively, meme creativity 
often uses visual objects that connote degrading other people, including exploiting women's bodies. The act of degrading other people is included in acts of gender discrimination, including sexual harassment of women. This has been regulated in UU No. 7 of 1984 About Convention on the Elimination of All Forms of Discrimination Against Women, in particular Part 1 Article 5(a), "To modify the social and cultural patterns of conduct of men and women, with a view to achieving the elimination of prejudices and customary and all other practices which are based on the idea of the inferiority or the superiority of either of the sexes or on stereotyped roles for men and women" [3]

In addition, visualizing the body of women with a tendency to sexually exploit also considered to violate UU No. 44 of 2008 concerning Pornography, especially Part 1 Article 1 which reads "Pornography is a picture, sketch, illustration, photo, writing, sound, moving image, animation, cartoon, conversation, gesture, or other forms of message through various forms of public media communication and/or performance, which includes sexual obscenity or exploitation that violates moral norms in society " [4].

Visualization of memes with discriminatory and pornographic images as mentioned above can be considered as not following ethical requirements. Ethics is defined as a science that addresses rights and obligations about morals, about everything that is considered good and bad. That is, the existence of meme designs that connote pornography and degrading other people, cannot be separated from human moral responsibilities and obligations. Humans as socio-cultural beings are bound by the values that exist in their society and need to maintain ethics for the future community.

This study formulated the research question: How is the deconstruction of ethics more responsible through meme design? Deconstruction of ethics in meme design means ethical rearrangement of meme visualization. The combination method is used to discuss design elements as ethical messages in the visual culture of memes. Quantitatively, this study conducted a survey of 150 design students to find out their views as creators. The respondent's sample was intended to build the perceptions of design students about the creation of memes based on ethics of responsibility. The principle of responsibility is part of the ethics of the 20th Century formulated by Hans Jonas, namely the ethics of the future in the context of addressing technological developments. Whereas qualitatively, the problem of visual language is included in the science of visual communication design, so this study uses sociology of design approach to discussing design solutions through reading the visual signs function that is in accordance with the ethical responsibility.

The results of this study can encourage audiences to be critical of meme designs that are not in accordance with moral norms. It can also be a scientific reference, as well as building awareness of the public to understand the visual language of memes and not spreading memes that can bring negative impact messages, especially regarding gender discrimination and connotating pornography.

\section{Methods}

This study uses a combination of qualitative and quantitative methods, which shown on the following analysis chart. 


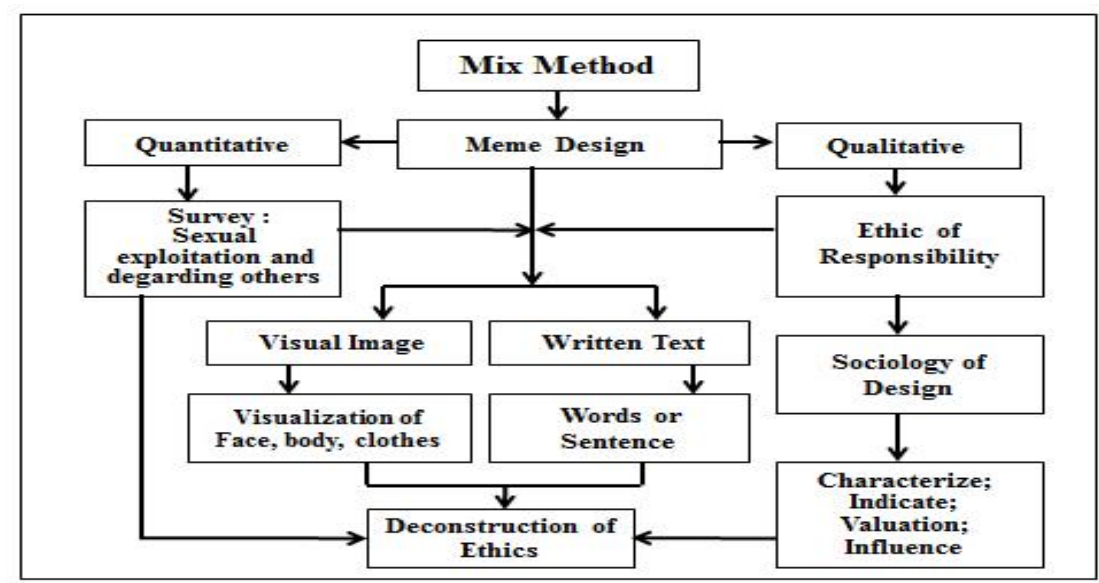

Figure 1. Analytical Method

Qualitative methods are used to obtain data about the tendency of memes on social media which displays a lot of social exploitation and demeaning others, whereas qualitative methods with sociology of design approach are used to analyze the ethical deconstruction by reading the function of visual signs.

\section{Result and discussion}

Gender discrimination actions, in the form of sexual harassment, can occur in cyberspace through photos uploaded and shared on social media. In the BKKBN technical book, it was explained that "Sexual harassment refers to sexual nuances that are conveyed through physical and non-physical contacts that target a part of a person's sexual body or sexuality to cause discomfort, demeaning a person, and possibly causing health problems and threatening safety " [5].

Photos or images that sexually exploit a woman's body also connote pornography. Pornography is an act that puts sexuality improperly and violates moral norms, such as doing naked poses or styles that harass or disrespect human dignity. Pornography is one form of action that essentially violates the value of propriety and morality in society [6].

In the meme design, the reading of visual signs is based on visual elements of images and written text. According to Elkins, each visual image has a visual strength that can construct the meaning of interpretation and this cannot be separated from the user's memory[7]. Therefore meme designs that are not ethically compatible have the potential to build certain perceptions that are wrong, especially in addressing social issues in society. Meme design communicates through images and written text to its users. In visualizing images, meme generally displays visual elements of the face, body, complete with clothes as a visual object, including settings. In addition, in written text, meme display short words or sentences to convey their intentions.

\subsection{Ethic of Responsibility}

Philosophical figure Hans Jonas said that dynamic technological developments had encouraged humans to develop ethics that are not bound to certain principles other than positive attitudes, but all focus on the consequences of human actions. Hans Jonas also put 
forward the ethics of the future starting with two obligations: first is the heuristics of fear, where feelings of fear make people moved to build fantasies about the long-term consequences of the dynamics of technological civilization. While the second is to build feelings that are in accordance with what is imagined so that this builds emotional motivation that encourages people to change the way they produce and consume. There are four principles of responsibility for future ethics that can be used as guidelines: Act in such a way that the consequences of your actions can be reconciled with the preservation of true human life on earth; Act in such a way that the consequences of your actions do not damage the possibilities of life like that in the future; Do not endanger the conditions of the infinite preservation of humanity on earth; In your choice now, future human wholeness must be part of the purpose of your will [8].

\subsection{Sociology of Design}

Theoretically, sociology of design is the study of individual behavior, a group of people or society that is influenced by certain design works or vice versa, namely design works that create certain social situations with comprehensive approaches [9]. The meme design creativity that has the potential to form the connotation of gender discrimination and the tendency of pornography needs to be overcome with a sociological design approach to solve social problems in society. In this case, the design solution effort needs to consider design elements that display images and text more responsibly. In the communication process, meme designs must be tailored to the interests of the user as communicants who read the visual signs function to: indicate; characterize; realize the problem; valuation, positive or negative; influence audience to maintain or change the status-quo; control, activity or function; achieving goals or purpose [10].

The results of surveys by using Guttman Scale, about the tendency of meme designs on social media to 150 design students at Universitas Indraprasta Jakarta, show the following data: $56 \%$ of students consider meme designs tend to display photos with sexual exploitation. $73 \%$ of students consider meme designs tend to make fun of and demean other people. $59 \%$ of students consider meme designs need to follow the rules and ethics. The results of the data illustrate the tendency to deliver messages through memes that are not ethical. Submitting information through memes has the potential to influence public opinion. According to F. Handayani et al., this is because the representation of public opinion in the form of memes is more beneficial, can be a multi-interpretation and attractive [11].

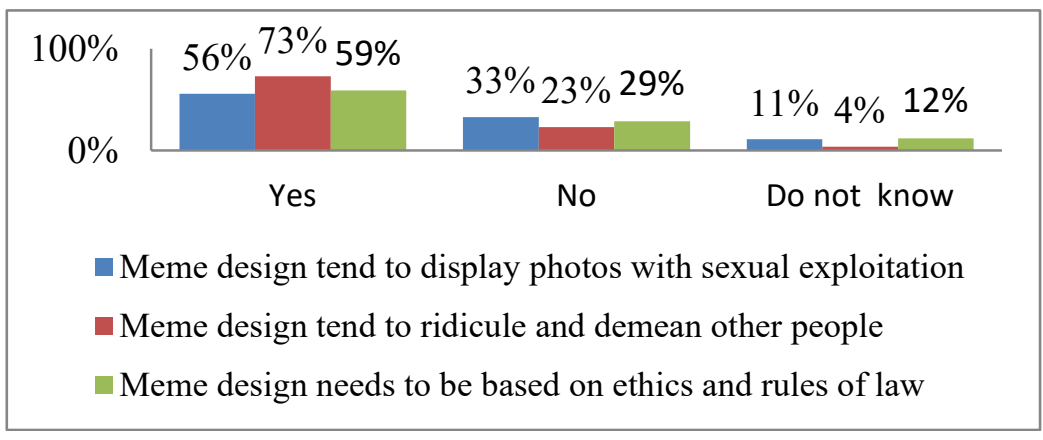

Figure 2. Percentage of respondents' views on meme designs 
That's the positive impact of memes. However, what needs to be underlined is what if the delivery of messages about issues or social criticism through memes on social media is less ethical, so the images and texts displayed tend to create perceptions that are not in accordance with social norms. The tendency to convey meme messages in a humorous style is one of the factors that influence the meme creation process. There is also limited knowledge of users of social media about ethics in electronic interactions. This study reaffirms the importance of memes that refers to the principle of responsibility.

In the context of sociology of design, meme design is inseparable from the role of social media users. Morissan shares the role of these users as Watchers, users who want to help themselves to make decisions. Sharers, users who like to upload information and share it with others. Commenters, users who like to comment on a product or event as a form of participation. Producer, users who produce their own content as a form of identity to be recognized by the public [12]. The four roles are closely related to the creation and dissemination of memes on social media, and the role of the user needs to always consider its actions in producing and consuming meme designs so that the impact does not undermine human integrity to become an informative and communicative society globally. In the communication process, meme are read by users to characterize what they see, indicate clues, give value about good or bad, and encourage influence, so the message of the meme can affect others.

Table 1. Deconstruction of Ethic of Responsibility in Meme Design

\begin{tabular}{|c|c|c|c|c|}
\hline \multirow[b]{2}{*}{ Meme Design } & \multirow[b]{2}{*}{ Visual Elements } & \multirow[b]{2}{*}{ Reading of Signs } & \multicolumn{2}{|c|}{ Ethic of Responsibility } \\
\hline & & & $\begin{array}{l}\text { Without } \\
\text { exploitation }\end{array}$ & $\begin{array}{l}\text { Without degrading } \\
\text { others }\end{array}$ \\
\hline \multirow[t]{3}{*}{ Image } & Face & Characterize & $\begin{array}{l}\text { Not tempting } \\
\text { expression }\end{array}$ & $\begin{array}{l}\text { Not to be made } \\
\text { fun of }\end{array}$ \\
\hline & Body & Indicate & Nobody exploitation & Not to be ridiculed \\
\hline & Clothes & Valuation & Custom manners & Neat clothes \\
\hline Written Text & Word/sentence & Influence & Positive connotation & $\begin{array}{l}\text { Motivating } \\
\text { wise }\end{array}$ \\
\hline
\end{tabular}

The table above can be a reference, that the issue of gender discrimination through the exploitation of the body, especially women, and the tendency to demean others through visualizing memes that are not ethically appropriate becomes important, because of the potential influence of memes on large social media. In Mahanani's research, it is said that the effect of communication technology has an influence on changes in human behavior and ways of thinking in social life from various perspectives [13]. Awareness of the potential for this influence is often misused for the subjective interests of social media users and is not based on the importance of the integrity of human life in the future. Continuing ethical violations can have an impact on diminishing moral values.

\section{Conclusion}

Briefly, this study concludes, the creativity of memes that exploit one's body, especially women as visual objects, can be categorized as not in accordance with the principle of responsibility in the ethics of the future. The memes that visualize gender discrimination and 
has a tendency towards pornography are considered contrary to UU No. 7 of 1984 and UU No. 44 of 2008. Deconstruction of ethics in memes on social media can be applied through visual elements of images and visual elements of the written text that do not demean other people, including not ridicule, but must be motivating and wise. It is forbidden to exploit anyone's body that has tempting connotations but must be visualized politely according to the prevailing norms. Social media users need to be critical of meme designs that unethical by not participating in uploading and disseminating them. The creators are also encouraged not to produce memes that violate moral norms, so it builds up the responsible ethics of the future

\section{References}

[1] A. Adhiwijayanti, Meme Dibaca Mim. Jakarta: Bukune, 2015.

[2] N. Mirzoeff, An Introduction to Visual Culture, 2nd Editio. United Kingdom: Routledge, 2009.

[3] Presiden Republik Indonesia, Undang-Undang Republik Indonesia Nomor 7 Tahun 1984 Tentang Pengesahan Konvensi Mengenai Penghapusan Segala Bentuk Diskiriminasi Terhadap Wanita. 1984.

[4] Presiden Republik Indonesia, Undang-Undang Republik Indonesia Nomor 44 Tahun 2008 Tentang Pornografi. .

[5] Badan Koordinasi Keluarga Berencana Nasional, Buku Suplemen Bimbingan Teknik Kesehatan Reproduksi Pelecehan seksual. Jakarta: UNESCO, 2013.

[6] H. Christianto, "Norma Kesusilaan sebagai Batasan Pornografi menurut Undangundang No. 44 Tahun 2008," J. Huk. Pembang., vol. 40, no. 1, pp. 23-51, 2008.

[7] K. K. Murray, "DNA Sequencing by Mass Spectrometry," J. Mass Spectrom., vol. 31, no. 11 , pp. 1203-1215, Nov. 1996.

[8] F. Magnis-Suseno, 12 Tokoh Etika Abad ke-20. Yogyakarta: Kanisius, 2000.

[9] A. Sachari, Sosiologi Desain. Bandung: Penerbit ITB, 2002.

[10] J. Sutarso, "Perempuan, Kekuasaan, dan Media Massa: Sebuah Studi Pustaka," KomuniTi, vol. IV, no. 1, pp. 1-17, 2012.

[11] F. Handayani, S. D. S. R. Sari, and W. Respati, "The Use of Meme as A Representation of Public Opinion in Social Media: A Case Study of Meme About Bekasi in Path and Twitter," Humaniora, vol. 7, no. 3, p. 333, Jul. 2016.

[12] Morissan, "Morissan: Media Sosial dan Partisipasi Sosial," Visi Komun., vol. 13, no. 1, pp. 50-68, 2014.

[13] P. A. R. Mahanani, "Media Sosial dan Gaya Komunikasi," Komunikator, vol. 6, no. 1, pp. 59-69, 2014. 